\section{Field Evaluation of Cold Hardy Citrus in Coastal Georgia}

\author{
Mark Rieger, ${ }^{1}$ Gerard Krewer, ${ }^{2}$ \\ Pam Lewis, ${ }^{3}$ Mindy Linton, ${ }^{3}$ \\ and Tom McClendon ${ }^{4}$
}

Additional INDEX WORDs. kumquat, citrangequat, mandarin, satsuma, freezing stress, frost

Summary. Sixteen cultivars of citrus (Citrus spp.) and close citrus relatives were planted in Savannah, Georgia to evaluate their potential as fruiting landscape trees in an area that routinely experiences minimum temperatures of 15 to $20^{\circ} \mathrm{F}\left(-9.4\right.$ to $\left.-6.7^{\circ} \mathrm{C}\right)$ during winter. Three to six trees of each cultivar were planted in 1998 , and stem dieback and defoliation data were collected in 1999, 2001, and 2002. During the 4 years of the study, air temperatures fell below $32{ }^{\circ} \mathrm{F}(0.0$ $\left.{ }^{\circ} \mathrm{C}\right) \mathbf{2 7}$ to 62 times per season, with absolute minima ranging from 13 to $18^{\circ} \mathrm{F}\left(-10.6\right.$ to $\left.-7.8^{\circ} \mathrm{C}\right)$, depending on year. In general, kumquats (Fortunella spp.), represented by 'Meiwa', 'Nagami', and 'Longevity', were completely killed (or nearly so) in their first year in the field after air temperature minima of $13.5^{\circ} \mathrm{F}\left(-10.28^{\circ} \mathrm{C}\right)$. Others experiencing $100 \%$ dieback were 'Meyer' lemon (Citrus limon x C. reticulata) and 'Eustis' limequat ( $C$. aurantifolia $\times$ Fortunella japonica), which were tested twice during the study. Kumquat hybrids, including procimequat $[$ (C. aurantifolia $\times$ F. japonica) x F. hindsii), 'Sinton' citrangequat [(C. sinensis $\mathrm{x}$ Poncirus trifoliata $)$ $\mathrm{x}$ unknown kumquat], 'Mr John's Longevity' citrangequat [(C. sinensis x P. trifoliata) x F. obovat $]$, razzlequat (Eremocitrus glauca $\mathbf{X}$ unknown kumquat), and 'Nippon' orangequat ( $C$. unshiu $\times$ F. crassifolia) survived freezing, but all experienced at least some defoliation and stem dieback. 'Owari' satsuma (C. unshiu), 'Changsha' mandarin (C. veticulata), nansho daidai (C. taiwanica) and ichang papeda (C. ichangensis) experienced only minor stem dieback but substantial defolia-

${ }^{1}$ Department of Horticulture, University of Georgia, Athens, GA 30602.

${ }^{2}$ Department of Horticulture, Rural Development Center, P.O. Box 1209, Tifton, GA 31793.

${ }^{3}$ Coastal Gardens Research Farm, \#2 Canebrake Rd, Savannah, GA 31419

${ }^{4} 205$ East North St., Greensboro, GA 30642. tion in most years, except that ichang papeda was substantially damaged in the last year of the study. Seven cultivars produced fruit at least once during their first 4 years: nansho daidai, ichang papeda, 'Nippon' orangequat, 'Mr John's Longevity' citrangequat, 'Owari' satsuma, 'Changsha' mandarin, and procimequat. Based on cold hardiness, fruiting, and growth characteristics, 'Owari' satsuma, 'Changsha' mandarin, 'Mr John's Longevity' citrangequat, and 'Nippon' orangequat provided the hardiest, most precocious and desirable fruiting landscape trees in this study.

$\mathrm{H}$ omeowners in areas colder than the nation's traditional citrus producing regions desire to grow many non-commercial citrus cultivars and close relatives [trifoliate orange (Poncirustrifoliata), kumquats, and hybrids thereof) that make attractive landscape trees and produce edible fruit. Although estimates of hardiness vary depending on source, some are touted as being cold hardy to single digit or teens Fahrenheit $\left(-7\right.$ to $\left.-15^{\circ} \mathrm{C}\right)$, and would therefore be suitable for warm-temperate and coastal areas of the southeastern U.S. However, claims of hardiness are often poorly documented, and fluctuating winter temperatures characteristic of this region may result in poor cold acclimation (Davies and Albrigo, 1994), which prevents attainment of maximum hardiness.

Scant documentation exists for successful dooryard cultivation of hardy citrus cultivars in the southeastern U.S. (Krewer and Powell, 1983; McCLendon, 200la, 2001b). Trees are often observed in the landscape, particularly in coastal areas with warm microclimates. Anecdotal reports of trees surviving and fruiting are valuable collectively, but multi-year tests of these cultivars with documented temperature data are unavailable. This study was undertaken to evaluate the hardiness and growth characteristics of several candidate cultivars at a site that routinely experiences minimum temperatures of 15 to $20^{\circ} \mathrm{F}$ during winter.

\section{Materials and methods}

Site. The Coastal Gardens Research Farm (lat. $32^{\circ} \mathrm{N}$, long. $81^{\circ} \mathrm{W}$ ), in Savannah, Ga., about 20 miles (32.2 $\mathrm{km}$ ) from the coast was used for the study. This site has a rather cold microclimate relative to the surrounding region and has an automated weather station that records air temperature, precipitation, and other weather variables. The soil type is an Albany Fine Sand.

Plot AND CULtural CONDITIONS. Trees were spaced 8 to $12 \mathrm{ft}$ (2.4 to $3.7 \mathrm{~m}$ ) apart in east-west oriented rows that were about $20 \mathrm{ft}(6.1 \mathrm{~m})$ apart, on raised beds 12 tol 6 inches $(30.5$ to $40.6 \mathrm{~cm})$ in height and $5 \mathrm{ft}$ $(1.5 \mathrm{~m})$ wide to improve drainage. Beds were mulched with wood chips to control weeds and conserve moisture. The planting was fertilized twice annually with $14 \mathrm{~N}-6 \mathrm{P}-11$.6K slow-release fertilizer (Osmocote; The Scotts Co., Marysville, Ohio) or a granular $10 \mathrm{~N}-4.4 \mathrm{P}-8.3 \mathrm{~K}$ source, and irrigated as needed. An overhead irrigation system was used for routine irrigation and once for freeze protection during an unusually early and severe freeze on 21 Nov. 2000, [minimum temperature of $\left.18.9^{\circ} \mathrm{F}\left(-7^{\circ} \mathrm{C}\right)\right]$. Other than this date, trees were not irrigated for freeze protection. Shoots originating from the rootstock or on the lower 12 to 18 inches $(45.7 \mathrm{~cm})$ of the main trunk were removed each year. Dead wood was removed in the spring of each year after measurements of stem dieback were made. New growth flushes were sprayed with insecticide in the second, third, and fourth years to control citrus leaf miner (Phyllocnistis citrella) damage, and weeds within the beds were controlled with glyphosate herbicide.

Cultivars. Sixteen cultivars were obtained from commercial nurseries, and three to six trees of each cultivar were planted in Spring 1998, with the exception of 'Changsha' mandarin, where 30 trees were planted to provide plant material for an additional study. Unless otherwise noted, trees were grown on their own roots.

Kumquats. 'Meiwa', 'Nagami', and 'Longevity' were chosen to represent pure kumquat cultivars. 'Meiwa' and 'Nagami' were grafted on sour orange (C. aurantium) rootstock, and 'Longevity' was own-rooted.

Kumquat hybrids. Six cultivars with kumquat parentage included 'Nippon' orangequat, 'Eustis' limequat, procimequat, 'Sinton' citrangequat, 'Mr John's Longevity' citrangequat, and razzlequat. All kumquat hybrids were own-rooted except 'Eustis', which was grafted on sour orange rootstock. 'Eustis' limequat was replanted in Spring 2000 after all 
original trees were killed by freezing in the first year. One of three original ' $\mathrm{Mr}$ John's Longevity' trees killed by freezing was replaced with a tree budded on 'Carrizo' citrange (Citrus sinensis $x$ Poncirustrifoliata) rootstock Spring 2000; four additional trees, similarly propagated, were also planted at this time, bringing the total to seven for this cultivar.

Mandarins. 'Changsha', 'Owari' satsuma, and 'Snow Picked' (unknown Citrus reticulata; Oregon Exotics Nursery, Grants Pass, Ore.) were chosen based on reports of superior cold hardiness. 'Owari' was grafted on sour orange rootstock, and the others were own-rooted.

Other citrus species. Yuzu (Citrus junos), nasho daidai, ichang papeda, and 'Meyer' lemon were also chosen based on reports and observations of superior cold hardiness in southern Georgia. Only 'Meyer' was grafted (sour orange rootstock). 'Meyer' lemon was replanted in Spring 2000 , after all original trees were killed by freezing. Replanted 'Meyer' lemons were grown from rooted cuttings to allow for the possibility of resprouting from roots if trees were killed.

Data collection and analysis. Winter temperature data covering the 4- year period were recorded continuously at the Coastal Gardens Research Farm by an automated weather station; data were retrieved from archives at <http://www.griffin.peachnet.edu/ cgi-bin/GAEMN.pl? site=GASA $>$ (Hoogenboom, 2002). Stem dieback and defoliation were measured in Mar. 1999,2001 , and 2002, by measuring at least two stems on each tree of a given cultivar. All data presented were collected from at least three trees of a given cultivar. Percent dieback was calculated as (dead stem length/total stem length $) \times 100$, and percent defoliation was calculated as (\#remaining leaves /total node number $) \times 100$. Tree height, to the nearest $0.5 \mathrm{ft}(15 \mathrm{~cm})$ above the soil line were measured in November 2001, after four seasons in the field. At the same time, fruit number and weight per fruit were also measured, counting all fruit per tree, and weighing a representative fruit sample on a portable electronic balance. A thorniness rating was made on mature stems according to the following scale based on thorn length: 0 $=$ no thorns, $1=\leq 1 / 4$ inch $(6.4 \mathrm{~mm})$, $2=1 / 4$ to $1 / 2$ inch $(12.7 \mathrm{~mm}), 3=1 / 2$ to 1 inch $(25.4 \mathrm{~mm}), 4=1$ to 2 inches $(50.8 \mathrm{~mm}), 5=>2$ inches.

Data were analyzed by analysis of variance (ANOVA) and Tukey's mean separation, or ANOVA on ranks with Dunn's test to separate means when data were not normally distributed. Data on fruit weight and thorniness were not analyzed statistically due to high variation and low replication; they are provided for descriptive purposes only.

\section{Results}

Temperature data. Winter weather was typical for the site, with the exception of the 2000-01 winter, which had an unusually high number of freezes and record early and late freezes (Table 1). Temperature minima ranged from 13 to $18^{\circ} \mathrm{F}$, and all winters had characteristic fluctuating temperature patterns. High temperatures in the $60 \mathrm{~s}$ to $80 \mathrm{~s}{ }^{\circ} \mathrm{F}$ (upper teens to high $20 \mathrm{~s}$ ${ }^{\circ} \mathrm{C}$ ) often preceded freezes that ran several consecutive nights. Fluctuating temperatures tend to reduce the degree of cold acclimation in citrus and related species (Davies and Albrigo, 1994). Another factor that may have contributed to less than optimal ac- climation was tree age; young trees are generally less cold tolerant than older trees (Yelenosky, 1996). Thus, the study conditions presented a strong challenge in terms of freezing stress.

Cold hardiness rankings. 1999. Five cultivars were either completely killed or injured beyond the point of recovery after the first year in the field (Table 2). This included all three kumquats, 'Meyer' lemon, and 'Eustis' limequat. Of the three trees planted, one yuzu and two 'Snow Picked' mandarin trees were killed and not replant$\mathrm{ed}$, precluding further data collection. One of the 'Mr John's Longevity' trees was also killed, but trees were later replaced so this cultivar could continue to be evaluated. Considerable stem dieback and defoliation occurred for most of the kumquat hybrids, including procimequat, 'Nippon', 'Sinton', and 'Mr John's Longevity', but razzlequat was among the least damaged of the 16 cultivars studied. Two of the mandarins, 'Owari' and 'Changsha', also showed little or no stem dieback, similar to ichang papeda and nansho daidai.

2001. All of the replanted 'Eustis' and 'Meyer' trees were killed completely, as in 1999, during the unusually cold 2000-01 winter. Although 'Meyer' were own-rooted with the intention of reestablishing trees from surviving roots, no resprouting occurred from the roots the following spring. Nine of the 16 cultivars planted in 1998 experienced $28 \%$ or less stem dieback, with three cultivars showing no stem dieback (Table 3). The relatively small amount of stem dieback is somewhat surprising, given a temperature minimum of $13^{\circ} \mathrm{F}$ $\left(-10.5^{\circ} \mathrm{C}\right)$ for the year, about twice the normal number of freeze events, poor acclimation weather through November, and 26 consecutive nights below

Table 1. Winter weather data from Coastal Gardens Research Farm, Savannah, Ga. over the 4-year study; ${ }^{\circ} \mathrm{C}=5 / 9\left({ }^{\circ} \mathrm{F}-32\right)$.

\begin{tabular}{|c|c|c|c|c|}
\hline Year & $\begin{array}{c}\text { Nights } \\
<32{ }^{\circ} \mathrm{F} \\
\text { (no.) }\end{array}$ & $\begin{array}{l}\text { Nights } \\
<20{ }^{\circ} \mathrm{F} \\
\text { (no.) }\end{array}$ & $\begin{array}{l}\text { Min } \\
\text { temp } \\
\text { winter } \\
\left({ }^{\circ} \mathrm{F}\right)\end{array}$ & Comments \\
\hline 1998-1999 & 27 & 2 & 13.5 & $\begin{array}{l}\text { Unusually warm November and December preceded freezing on } 11 \text { of } 14 \text { nights in } \\
\text { January; l week of }>70{ }^{\circ} \mathrm{F} \text { preceded } 4 \text { freeze nights in late February down to } 22.1^{\circ} \mathrm{F}\end{array}$ \\
\hline $1999-2000$ & 44 & 7 & 16.2 & $10 \mathrm{~d}>70^{\circ} \mathrm{F}$ preceded 4 freeze nights in early December down to $19.9^{\circ} \mathrm{F}$ \\
\hline 2000-2001 & 62 & 12 & 13.1 & $\begin{array}{l}\text { Unusually early and record late freezes ( } 10 \text { Oct. and } 19 \text { Apr., respectively); highs in the } \\
70 \mathrm{~s} \text { and } 80 \mathrm{~s}^{\circ} \mathrm{F} \text { in October and November, only } 1 \text { week of normal temps preceding } 4 \\
\text { nights down to } 18.9^{\circ} \mathrm{F} \text { on } 21 \text { Nov. (irrigated this date for protection); below freezing } \\
\text { every night from } 17 \text { Dec. to } 11 \text { Jan., then } 21 \text { Jan. to } 29 \text { Jan. }\end{array}$ \\
\hline $2001-2002$ & 30 & 2 & 18.5 & $\begin{array}{l}\text { Early frost (late October) then warm }\left(60 \text { to } 80^{\circ} \mathrm{F}\right) \text { through } 20 \text { Dec., then } 13 \text { of next } \\
20 \text { nights below freezing down to } 18.5^{\circ} \mathrm{F}\end{array}$ \\
\hline
\end{tabular}


Table 2. Cold hardiness rankings for citrus and related cultivars after first year in field (1999), Coastal Gardens Research Farm, Savannah, Ga.

\begin{tabular}{lcc}
\hline Taxon & $\begin{array}{c}\text { Stem } \\
\text { dieback } \\
(\%)\end{array}$ & $\begin{array}{c}\text { Defoliation } \\
(\%)\end{array}$ \\
\hline 'Eustis' limequat & $100 \mathrm{a}^{\mathrm{z}}$ & $100 \mathrm{a}$ \\
'Nagami' kumquat & $100 \mathrm{a}$ & $100 \mathrm{a}$ \\
'Meyer' lemon & $100 \mathrm{a}$ & $100 \mathrm{a}$ \\
'Meiwa' kumquat & $83 \mathrm{ab}$ & $100 \mathrm{a}$ \\
'Longevity' kumquat & $78 \mathrm{ab}$ & $100 \mathrm{a}$ \\
Yuzu & $64 \mathrm{ab}$ & $100 \mathrm{a}$ \\
Procimequat & $59 \mathrm{ab}$ & $89 \mathrm{ab}$ \\
'Nippon' orangequat & $55 \mathrm{ab}$ & $58 \mathrm{ab}$ \\
'Snow Picked' mandarin & $54 \mathrm{ab}$ & $100 \mathrm{a}$ \\
'Sinton' citrangequat & $23 \mathrm{ab}$ & $81 \mathrm{ab}$ \\
'Mr. John's Longevity' citrangequat & $18 \mathrm{ab}$ & $71 \mathrm{ab}$ \\
Ichang papeda & $15 \mathrm{ab}$ & $79 \mathrm{ab}$ \\
'Changsha' mandarin & $8 \mathrm{~b}$ & $69 \mathrm{ab}$ \\
Nansho daidai & $6 \mathrm{~b}$ & $80 \mathrm{ab}$ \\
'Owari' satsuma & $0 \mathrm{~b}$ & $50 \mathrm{ab}$ \\
Razzlequat & $0 \mathrm{~b}$ & $16 \mathrm{~b}$ \\
\hline
\end{tabular}

${ }^{2}$ Data were not normally distributed; analyzed by analysis of variance on ranks with Dunn's mean separation. Means followed by the same lower case letter are not significantly different, $P<0.05$.

Table 3. Cold hardiness rankings for citrus and related cultivars with three or more individuals surviving after 3 years (2001), Coastal Gardens Research Farm, Savannah, Ga.

\begin{tabular}{|c|c|c|}
\hline Taxon & $\begin{array}{c}\text { Stem } \\
\text { dieback } \\
(\%)\end{array}$ & $\begin{array}{c}\text { Defoliation } \\
(\%)\end{array}$ \\
\hline 'Eustis' limequat ${ }^{\mathrm{z}}$ & $100 a^{y}$ & $100 \mathrm{a}$ \\
\hline 'Meyer' lemon ${ }^{\mathrm{z}}$ & $100 \mathrm{a}$ & $100 \mathrm{a}$ \\
\hline Procimequat & $28 \mathrm{ab}$ & $90 \mathrm{ab}$ \\
\hline Ichang papeda & $21 \mathrm{ab}$ & $71 \mathrm{ab}$ \\
\hline Razzlequat & $5 \mathrm{ab}$ & $91 \mathrm{ab}$ \\
\hline 'Owari' satsuma & $4 \mathrm{~b}$ & $77 \mathrm{ab}$ \\
\hline 'Changsha' mandarin & $3 \mathrm{~b}$ & $65 \mathrm{~b}$ \\
\hline 'Nippon' orangequat & $3 \mathrm{~b}$ & $43 \mathrm{~b}$ \\
\hline 'Sinton' citrangequat & $0 \mathrm{~b}$ & $74 \mathrm{ab}$ \\
\hline Nansho daidai & $0 \mathrm{~b}$ & $79 \mathrm{ab}$ \\
\hline 'Mr. John's Longevity' citrangequat ${ }^{\mathrm{x}}$ & $0 \mathrm{~b}$ & $72 \mathrm{ab}$ \\
\hline
\end{tabular}

freezing in December and January. Defoliation ranged from 43 to $91 \%$ on the nine surviving cultivars, but all showed signs of new leaf production in March 2001.

2002. Seven cultivars remained available for analysis following the winter of 2001-02 (Table 4). Three of the five remaining ichang papeda trees were killed by freezing, eliminating it from analysis. Two of three 'Nippon' orangequat trees died during the late fall of 2001 from root rot, not from freezing; the single remaining tree showed no stem dieback whatsoever, but was defoliated about 30\% to $35 \%$ (data not shown). Only procimequat, which was considerably damaged, showed more than $1 \%$ stem dieback. Defoliation was less than $30 \%$ in 'Changsha', razzlequat, and nansho daidai, but severe in the other cultivars.

GROWTH AND FRUITING CHARACTERISTICS. Six of the nine cultivars evaluated in November 2001, after four seasons of growth, had heights of $6 \mathrm{ft}(1.8 \mathrm{~m})$ or greater (Table 5). Procimequat and ichang papeda are reportedly small in stature, and were not expected to be strong growers. 'Owari' satsuma did not grow to $6 \mathrm{ft}$ also, but fruited heavily in 2000 and 2001, often bending limbs downward and causing some trees to lean. Furthermore, 'Owari' did not posses the largely upright growth habit of the other cultivars.

Seven of nine cultivars produced at least some fruit by Fall 2001; only razzlequat and 'Sinton' citrangequat did not produce fruit during the study (Table 5). Of the seven which fruited in 2001 , only two did not produce fruit the previous year as well (ichang papeda and nansho daidai, data not shown). Procimequat produced by far the most fruit per tree, estimated at up to 700 in the 2000 season. Fruit size was smallest in procimequat, and tended to be smaller in the kumquat hybrids than the mandarins or other citrus species. Eating quality was deemed best by the authors for 'Owari', 'Changsha', and 'Mr Johns Longevity'. 'Nippon' produced a tart, but edible fruit.

Thorniness was lowest in 'Owari', which was thornless, and greatest in nansho daidai and razzlequat (Table $5)$. These ratings were based on thorn length, not thorn density (number per unit length of stem) or firmness. However, the ratings shown should provide an indication of difficulty in pruning and picking fruit, and perhaps other practices affected by the presence of thorns.

\section{Discussion}

Our primary objective was to evaluate the suitability of several cold hardy citrus (and related) cultivars as fruiting landscape trees for regions of the southeastern U.S. that experience annual freezes in the 15 to $20^{\circ} \mathrm{F}$ range. Despite low replication due to plot size limitations, the temperature and hardiness data presented is quantitative and objective, as opposed to anecdotal reports from nurseries or homeowners who have made observations on single trees. Thus, the data should be interpreted cautiously, but serve to establish a baseline for choosing among the cultivars studied.

As a group, the kumquats ('Meiwa', 'Nagami', 'Longevity') did not survive freeze conditions of this study. This was somewhat unexpected, since they are known to be more cold hardy than commercially important citrus species, and exhibit prolonged quiescence in spring that reduces the 
Table 4.Cold hardiness rankings for citrus and related cultivars that survived through 4 years in the field (2002) with three or more individuals remaining, Coastal Gardens Research Farm, Savannah, Ga.

\begin{tabular}{lcc}
\hline Taxon & $\begin{array}{c}\text { Stem } \\
\text { dieback } \\
(\mathbf{\%})\end{array}$ & $\begin{array}{c}\text { Defoliation } \\
\mathbf{( \% )}\end{array}$ \\
\hline Procimequat & $82 \mathrm{a}^{\mathrm{y}}$ & $96 \mathrm{a}$ \\
'Mr. John's Longevity' citrangequat & $0.9 \mathrm{~b}$ & $69 \mathrm{a}$ \\
'Owari' satsuma & $0.7 \mathrm{~b}$ & $93 \mathrm{a}$ \\
Nansho daidai & $0 \mathrm{~b}$ & $17 \mathrm{~b}$ \\
Razzlequat & $0 \mathrm{~b}$ & $13 \mathrm{~b}$ \\
'Sinton' citrangequat & $0 \mathrm{~b}$ & $88 \mathrm{a}$ \\
'Changsha' mandarin & $0 \mathrm{~b}$ & $28 \mathrm{~b}$ \\
\hline 'All taxa planted in 1998 except five of seven 'Mr John's Longevity' citrangequat, which were planted in May \\
2000. \\
$\begin{array}{l}\text { 'Data were normally distributed; analyzed by analysis of variance with Tukey's mean separation. Means followed } \\
\text { by the same lower case letter are not significantly different, } P<0.05 .\end{array}$
\end{tabular}

Table 5. Growth and fruit characteristics of selected cultivars at the end of the fourth season, November 2001.

\begin{tabular}{|c|c|c|c|c|}
\hline Taxon $^{\mathrm{z}}$ & $\begin{array}{l}\mathrm{Ht} \\
(\mathrm{ft})\end{array}$ & $\begin{array}{c}\text { Fruit/ } \\
\text { tree } \\
\text { (no.) }\end{array}$ & $\begin{array}{l}\text { Wt/ } \\
\text { fruit }^{y} \\
\text { (g) }\end{array}$ & $\begin{array}{c}\text { Thorniness, } \\
\text { mature } \\
\text { wood }^{\mathrm{y}}\end{array}$ \\
\hline Nansho daidai & $10.4 \mathrm{a}^{\mathrm{x}}$ & $1 \mathrm{ab}$ & 230 & 2 to $3^{w}$ \\
\hline Razzlequat & $10.4 \mathrm{a}$ & $0 \mathrm{~b}$ & 0 & 2 to 3 \\
\hline 'Sinton' citrangequat & $9.4 \mathrm{ab}$ & $0 \mathrm{~b}$ & 0 & 1 to 2 \\
\hline 'Changsha' mandarin & $8.4 \mathrm{ab}$ & $39 \mathrm{ab}$ & 117 & 0 to 1 \\
\hline 'Nippon' orangequat & $7.2 \mathrm{abc}$ & $266 \mathrm{a}$ & 56 & 1 \\
\hline 'Mr. John's Longevity' citrangequat & $6.5 \mathrm{bc}$ & $77 \mathrm{a}$ & 35 & 1 \\
\hline ‘Owari’ Satsuma & $5.5 \mathrm{bc}$ & $37 \mathrm{ab}$ & 146 & 0 \\
\hline Procimequat & $4.6 \mathrm{c}$ & (hundreds) & $<5$ & 0 to 1 \\
\hline Ichang papeda & $3.6 \mathrm{c}$ & $8 \mathrm{ab}$ & 124 & 1 \\
\hline
\end{tabular}

likelihood of deacclimation in response to fluctuating temperatures in late winter (Jackson and Fasulo, 1994). Comparable results were obtained in northern Florida, where three of four 'Meiwa' trees were killed completely following a freeze on 23 Dec. 1989, with a minimum temperature of $12^{\circ} \mathrm{F}$ $\left(-11.1^{\circ} \mathrm{C}\right)$ (Anderson, 2000).

The kumquat hybrids displayed a wide range of hardiness, probably related to their parentage. Complete kill of 'Eustis' limequat, in both 1999 and 2001, was not surprising given the fact that limes are some of the least hardy citrus (Jackson and Fasulo, 1994). Procimequat, also with lime parentage, experienced substantial defoliation and $28 \%$ or greater stem dieback each year, which also may be expected. However, its survival compared to pure kumquat species is puzzling since one might expect partial lime parentage to reduce hardiness relative to pure Fortunella.
'Nippon' orangequat (half tangerine, half kumquat) performed relatively well in terms of cold hardiness and fruiting through Fall 2001, when two adjacent trees succumbed to root rot (caused by Phytophthora, diagnosed by J. Williams-Woodward). This may have been due to unfortunate placement in the field, or might suggest that this cultivar should be grafted on a rootstock tolerant of root rot fungi. The citrangequats, 'Sinton' and 'Mr Johns Longevity', proved to be among the hardiest of the original 16 cultivars. This was expected, due to the trifoliate orange parentage, and the fact that there is an old 'Thomasville' citrangequat tree at the Coastal Gardens Research Farm that has grown and fruited reliably for over 20 years. Razzlequat, with desert lime (Eremocitrus glauca) parentage, was probably the hardiest and one of the most attractive trees in the study, but lacked precocity and was extremely thorny. This cultivar may have potential as a security screen or hedgerow.

The mandarin group contained two of the best overall cultivars in the study, 'Changsha' and 'Owari'. The satsumas are known to be among the most cold hardy commercially cultivated citrus in the world (Ferguson, 1996), and have been cultivated successfully in relatively cold areas of the U.S. such as southern Mississippi, Alabama, Louisiana, and southern Georgia (McClendon 2001b). 'Owari' probably has the best quality fruit of all studied, being bright orange in color and nearly seedless, and has the added advantage of being thornless. The authors have observed several-year-old 'Changsha' growing and fruiting near Tifton and Augusta Ga, so this cultivar was expected to perform well. 'Snow Picked' mandarin, touted as hardy to 0 to $10^{\circ} \mathrm{F}\left(-17.2\right.$ to $\left.-12.2^{\circ} \mathrm{C}\right)$, was killed outright in the first year, raising doubts about the validity of those claims.

The four remaining cultivars, all species of Citrus, showed mixed results. 'Meyer' was killed outright both times tested (1999 and 2001), which was surprising since there are reports of it grown in Coastal Georgia, and it is listed in catalogs as hardy to teens ${ }^{\circ} \mathrm{F}\left(-11.7\right.$ to $\left.-7.2^{\circ} \mathrm{C}\right)$. Observations in northern Florida also showed that 'Meyer' had 0\% survival after experiencing $12{ }^{\circ} \mathrm{F}$ (Anderson, 2000). Nansho daidai exhibited greater cold hardiness than several cultivars, but was relatively thorny and slow to bear fruit. Yuzu was eliminated from the study after the first year when two of three trees died. Based on observations, and the use of yuzu in breeding other cold hardy cultivars (e.g., yuzange, yuzuquat, 'Clem-Yuzu 3-3'), we expected this cultivar to be more cold hardy. The single tree that survived grew to over $6 \mathrm{ft}$ by Fall 2001 , but was almost completely defoliated each year. Ichang papeda, reported as one of the most cold hardy of the evergreen citrus (McClendon, 2001a), had relatively little stem dieback in 2 of 3 years evaluated, but was severely injured in the last year. Its poor quality fruit and undesirable growth habit would likely render it undesirable to the homeowner.

A central question in relation to this study is "what constitutes cold hardiness?". In a landscape setting, aesthetics as well as fruit quality and yield become important. While the level of damage tolerated by homeowners is 


\section{VARIETY TRIALS}

likely to vary considerably, substantial annual stem dieback is unlikely to be tolerated by most people. If defoliation is the main criterion, clearly none of the cultivars tested would be considered cold hardy, since all experienced at least some degree of defoliation in most years. Alternatively, if one is willing to tolerate some defoliation and minor stem dieback, as long as the tree survives and fruits the following season, then cultivars such as 'Owari' satsuma, 'Changsha' mandarin, 'Mr Johns Longevity' citrangequat, and 'Nippon' orangequat would be considered cold hardy. These cultivars are quite attractive during the long fruiting season in late fall/early winter and deserve greater use as fruiting landscape plants in regions with climates similar to Savannah, Ga.

\section{Literature cited}

Anderson, P.C. 2000. Cold hardy citrus for north Florida. N. Fla. Res. Educ. Ctr. News. vol. 2. Feb. 72000.

Davies, F.S. and L.G. Albrigo. 1994. Citrus. Crop production science in horticulture. vol. 2. CAB Intl., Wallingford, U.K.

Ferguson, J.J. 1996. The satsuma tangerine. Univ. Fla. Fact Sheet HS 195.

Hoogenboom, G. 2002. Georgia automated environmental monitoring network. I May 2002. <http:// www.griffin.peachnet.edu/cgi-bin/ GAEMN.pl? site $=$ GASA $>$.
Krewer, G.A. and A.A. Powell. 1983. Citrus fruit for southern and coastal Georgia. Ga. Coop. Ext. Serv. Bul. 804

Jackson, L.K. and T.R. Fasulo. 1994. Cold hardy citrus. Univ. Fla. Fact Sheet HS 123.

McClendon, T.2001a. Citrus for the south: Part 1 of 2. Rapidophyllum: J. S.E. Palm Exotic Plant Soc. (Spring 2001):5-8.

McClendon, T.2001b. Citrus for the south: Part 2 of 2. Rapidophyllum: J. S.E. Palm Exotic Plant Soc. (Summer 2001):5-9.

Yelenosky, G. 1996. An overview of Florida citrus freeze survival. Proc. Fla. State Hort. Soc. 109:118-123. 